\title{
CONSUMERS' POSITIVE AND NEGATIVE REVIEWS TOWARDS LOCAL FOOD EXPERIENCES: THE CASE OF RESTAURANTS IN GAZIANTEP CITY ON TRIPADVISOR.COM
}

\author{
Caner Çalişkan ${ }^{1}$ \\ Hülya Yeşilyurt ${ }^{2}$ \\ Ozan Güler ${ }^{3}$ \\ Seçkin Kodal ${ }^{4}$
}

\begin{abstract}
Local flavor managements are the essential components of vacation and destinations. Most of the tourists taste local food and beverages that presents local culture during their vacations and tell these experiences to the people around them. At this point, one of the efficient ways for transferring these food and beverage experiences is the social media. Today, through social media which reaches to an important number of users, many individuals share their gastronomy experiences with their friends and others and form references with their positive or negative comments. Within this study, by using this important sharing world that internet provides as a starting point, the users' social media comments on food and beverage managements in Gaziantep, the city which is included in UNESCO Creative Cities Network from Turkey, was aimed to be searched. Under this scope, 1462 comments belong to the top 7 food and beverage managements in Gaziantep, on interactive forums of TripAdvisor which is an important travelling web-site were analyzed. According to the results, managements' food and beverage qualities and service qualities got the most positive comments whereas most negative comments were done on atmospheres and prices within these managements.
\end{abstract}

Key words: Local Flavor, Food and beverage managements, TripAdvisor, Gaziantep

\section{INTRODUCTION}

Food concept is both an important part of social life and an important metaphor within psychological, social and symbolic parts. Many individuals spend huge amounts of money for experiencing different flavors on their vacations. Besides, eating contains a symbolic meaning other than just being nutrition. In fact, some dishes symbolize excellence and being based on pleasure whereas some of them symbolize a culture and belongings to that culture according to the customers (Bessière, 1998: 23; Şengül and Türkay, 2015:2). In short, eating can be a tool for learning new cultures, socializing and

\footnotetext{
${ }^{1}$ Research Asst., PhD. Department of Tourism Management, Tourism Faculty, Adiyaman University, P.C.:02040, Adiyaman

${ }^{2}$ Research Asst., Department of Tourism Management, Tourism Faculty, Adiyaman University, P.C.:02040, Adiyaman/Turkey

${ }^{3}$ Research Asst., Department of Tourism Management, Tourism Faculty, Mersin University, P.C.:33343, Mersin/Turkey/ Corresponding author:ozanguler17@hotmail.com

${ }^{4}$ Research Asst., Department of Tourism Management, Tourism Faculty, Adiyaman University, P.C.:02040, Adiyaman/Turkey
} 
also resting the mind other than just being a tool for fulfilling basic needs (Kodaş and Dikici, 2012: 52).

On the other hand, today individuals start to deal with what they are eating and drinking more than ever and this became a newsworthy factor for social media (Kesici, 2015: 33). Because of that reason, food concept, which became way more than a physiological need and became an important component of culture, might be an attraction reason for a specific area where it is served, or might be a travelling reason only itself (Erkol and Zengin, 2015: 600). Food and geography and the places where these dishes are served become an important tool for experiencing the life. Thus, while food concept and places where this food is served is becoming a consumption tool for popular culture, consumption periods' effects on individuals become the symbol for pleasure (Silsüpür, 2016). Hence, it becomes inevitable that eating experiences are shared by consumers, which contains a large part of social life.

In our era, in which thoughts and opinions of individuals changes continuously (Taylan and Arıkan, 2008) consumers want to be consciously or unconsciously visible on all platforms by sharing their social life experiences like eating or drinking (Eraslan , Uludağ, 2013). By this instinct, many people want to share their eating experiences on social media and transfer these experiences to the large masses by their comments. If the social media is thought as the most effective and most common platform for today's sharing world (Vural Akınc1 and Bat, 2010), effects and realities of the comments shared on these platforms are increasing. From this point on, in this study, comments about local flavors that are served in food and beverage restaurants of Gaziantep, the city which was registered as UNESCO Creative Cities Network Gastronomy City, on social media were analyzed. By doing this, information that food and beverage managements of the city and local municipalities and non-governmental organizations that are responsible for UNESCO membership, can benefit from were released.

\section{LITERATURE REVIEW}

\section{Local Flavor}

Food and culture are two concepts that complete each other. Food concept presents a cultural communication area and has become a sign for local culture in time (Tellström, Gustafsson and Mossberg, 2006). While this feature turns local flavors into an attraction point for customers, it also helps protecting the culture which is supported by flavors, and transferring to the next generations (K1z1lırmak, Albayrak and Küçükali, 2014). On the other hand, the dishes that present local culture against the cultures that start to be same, might be a satisfaction tool for customers and a distinguishing tool for places (Zengin, Uyar and Erkol, 2014; Zağralı and Akbaba, 2015). However, preparing local flavors and presenting them according to their own rituals requires a risky and hard process (Aslan, Güneren and Çoban, 2014). So, changing a customary flavor 
within the scope of tradition and developing it without changing its texture is an important parameter for a culture to survive (Ekici, 2008).

\section{Gaziantep Cuisine Culture}

Gaziantep is a significant example of the richest cuisine cultures within Turkey and the variety of ingredients that are used in dishes reflect its properousness of its' strong cuisine culture (Özlü, 2006). Gaziantep cuisine has a great variety of agricultural products, such as grains, legumes, vegetables, fruits, Gaziantep pistachio, dozens of different local herbs and spices that enable to create more than 400 unique dishes and 291 species of them have already been registered (Gastroantep, 2016). Also, cusine culture became a symbol and an important component for customs and rituals that can survive today in Gaziantep (Sabbağ, 2015). That is, with this feature Gaziantep became one of the 17 members of UNESCO Creative Cities Network's Gastronomy Cities around the world, and the first from Turkey (UNESCO, 2015).

With the influence of variety of religions, climate, geography and civilizations and all sorts of living modes, Gaziantep today is promoted as the "Capital of Tastes" (Ertaş and Karadağ, 2013; Dailysabah.com, 2016). Particularly, the effects of Arab diets with spice and hot pepper are quite obvious on the South-Eastern cuisine culture (Özlü, 2006; Karadağ, 2009). Another significant mixer of the Turkish cuisine culture was Ottoman Empire because of its 600 years regnal duration and the number of countries under its control (Gaziantepmutfagi, 2016). Moreover, Mediterranean climate and fertile soils are the main reasons to provide numerous amounts of agricultural products for yummy cuisine of Gaziantep (Gastroantep, 2016). Besides, diversity in agricultural products, cooking techniques and consuming techniques are the known secrets of the Gaziantep's thousands of years food culture (Ertaş and Gezmen Karadağ, 2013; Gaziantep mutfagi, 2016).

\section{The Importance of Social Media in terms of Customers' Restaurant Experiences}

For today's societies acts of eating-drinking means not only fulfilling physical needs but also experiencing differences and re-exploring the local culture (Cömert and Özata, 2016). While this situation reflects on tourism too, today, alternative chances rather than sea-sand and sun are used and new experiences are searched like chasing the local flavors (Serçeoğlu, Boztoprak and Tırak, 2016: 95). In this context, social media became an important catalytic for before mentioned eating-drinking habits to become widespread. With a similar point or view, social media is an important factor for each management that serves under the scope of tourism. So, the tourists' sharing positive or negative experiences with large masses in a short time can be both an opportunity and a risk factor or for tourism managements (Sü Eröz and Doğdubay, 2012: 134).

Social media which is the most effective platform in terms of communication process for individuals (Özaslan and Uygur, 2014), is also an important information field for 
exploring customer behaviors. Today, thousands of individuals share their comments on foods or photos on foods that they prepare, eat or see on social media. They can do this both on their individual social media accounts or platforms that are opened specifically for food sharing (Eryılmaz and Şengül 2016). Social media sharings contains huge importance for food and beverage managements like many other managements. Customers compare services and products that they experiences on any level of their consumption with their needs. If whole performance is above their expectation they can show over satisfaction, if it is equal with their expectations they show satisfaction if it is under their expectations then they show low satisfaction and (Oliver, 1980; Baker and Crompton, 2000) so complaining occurs (Kolodinsky and Aleong, 1990). In this terms, social media presents many positive (positive WOM, loyalty) or negative (negative WOM, quit) opportunities for food and beverage managements by shaping the potential customers' expectations. Former studies showed that, customers give great importance on atmosphere, service quality, food-beverage quality and price and shape their future behaviors and their eating experience satisfaction according to these qualifications. (Sulek and Hensley, 2004). So, it is obvious that positive or negative social media comments on the criteria that are important for customers might shape the consuming behaviors for eating experiences.

\section{Literature Review on Consumer Expectations from Restaurants}

There are many studies on factors that lead to customer complaining on services and the restourant qualities that are important for them. These studies seem to focus on fast food restoranlar, local restaurants, casual restaurants, ethnic restairants, fine - dinign / upscale restaurants' customers. From this point of view, the factors that are most important within a restourant for customers according to those studies are summarised on Table 1.

Table 1. Important factors for Customers in a Restaurant

\begin{tabular}{|l|l|}
\hline Author & Key Factors \\
\hline Elder, vd. (1999) & Cleanliness, flavor, atmosphere, price \\
\hline Law, To and Goh (2008) & $\begin{array}{l}\text { Personnel attitude, hygiene, service speed, price, food and } \\
\text { beverage quality, atmosphere, service presentation. }\end{array}$ \\
\hline Lee, et al. (2012) & $\begin{array}{l}\text { Clean kitchen, hygiene of baking and heating tools, } \\
\text { freshness and ingredients of the food, investigation and } \\
\text { bathroom cleanliness }\end{array}$ \\
\hline $\begin{array}{l}\text { Namkung and Jang } \\
(2007)\end{array}$ & Flavor and presentation of the food. \\
\hline Heung and Hu (2012) & $\begin{array}{l}\text { Attraction of the restaurant, comfortable image and inner } \\
\text { design }\end{array}$ \\
\hline Korkmaz, (2005) & Cleanliness, healthy products, quality, fast service and \\
\hline
\end{tabular}




\begin{tabular}{|l|l|}
\hline & satisfying food \\
\hline $\begin{array}{l}\text { Tayfun ve Tokmak } \\
(2007) .\end{array}$ & $\begin{array}{l}\text { Appropriate flavor, on time service, placement to work- } \\
\text { house and accessibility }\end{array}$ \\
\hline $\begin{array}{l}\text { Yazıcıŏlu, Işın and Koç } \\
\text { (2013) }\end{array}$ & $\begin{array}{l}\text { Freshness, flavor, heating of food, product variety on } \\
\text { menus, price worthy }\end{array}$ \\
\hline $\begin{array}{l}\text { Şahin, Çakıcı and Güler } \\
\text { (2014) }\end{array}$ & Food security, hygiene \\
\hline
\end{tabular}

Factors that lead to customer complaints in terms of restoran managements is an other issue that was studied within literature. In the study of $\mathrm{Su}$ and Bowen(2000) most common problems that customers face with within a la carte restourants are listed as " slow and insufficent service', ' not baking enough', 'not worth that money' and ' rude service' . Similarly Liu and Jang (2009) stated that the most two important factor that are need to be developed within Chinese restourants for customers are 'hygiene and polite-tidy personnel'. In Kitapç's study (2008), 57,4 \% of the customers are found to complain about insufficent customer-personnel relation, slow service and insufficent service and restourant cleanliness. Zhang et al. (2010) concluded that food, service and atmosphere are the important factors within the study where they investigated online comments to retourants. Within the study of Albayrak (2013) attitude and behavior of the personnel, hygiene of personnel and flavor of food and beverages are the leading issues that are complained about most by customers. Şahin, Çakıcı and Güler (2014) listed the reasons that customers make complaints about a la carte restourants as restourant atmosphere and personnel service . Dalgıç, Güler and Birdir (2016) who explored the negative customer comments on local fast food restourant experiences in Mersin and Hatay customers wrote on Tripadvisor.com internet portal found that most negative comments have been left on food and service; most important sub-problems are flavor, personnel attitude, originality of food and fair prices. Arsezen Otamış (2015) within their study where they investigate customer comments on beverage and food restourants in Fethiye which are registered to Tripadvisor, found out that positive factors are on service quality and food quality; whereas negative factors are price and atmosphere. Similarly Lei and Law (2015) investigated positive and negative comments on a la carte restourants in Macau through Tripadvisor.com and the factor that got most negative comments was found as price.

\section{PURPOSE AND METHOD OF THE STUDY}

Purpose of the study is to investigate social media comments about food and beverage managements in Gaziantep, the city which was included in creative city web from Turkey, and make offers to applicators. Within the scope of study, social media comments through managements are analyzed with descriptive analysis process that is suggested by Walcott, Strauss and Corbin and has four stage; forming a descriptive 
analysis frame, analyzing data according to the themes, describing the results and commenting on the results (Yıldırım and Şimşek, 2011). In order customer comments to code right and gather under the right themes as suggested by descriptive analysis, former studies were investigated. In terms of coding word decisions; 15 words (code) within Su and Bowen's (2001) study that were used mostly for the problems and 25 expressions for customer complaints (codes) from Albayrak's (2013) study were used as a base. Written complaints which have those codes later classified into four main themes as stated within studies of Liu and Jang (2009) and Lei and Law (2015). By doing this complaint reasons are tried to be found.

Population of the research consists of the comments on food and beverage managements in Gaziantep from an important online-travelling web site, TripAdvisor. Although there are many web sites for customer complaints, TripAdvisor was chosen because of being internationally known, having huge numbers of active users , expertness on tourism industry, user friendly basis and giving feedback to users (Dalgıç, Güler and Birdir, 2016). Because of having huge numbers of food managements, sampling method was used. Three levels were done between 28.03.2016-15.04.2016 for data totals. Within the first level according to comment numbers, food and beverage managements that are in top 10 were used, within the second level 3 managements that serve one type of food and beverage were not included in the study. On the third level Turkish comments were included to analysis. As a result, a total of 1462 comments about 7 managements were included.

\section{RESULTS}

Data were analyzed within four different themes (food, service, atmosphere, and price) and two main headings positive/negative. Each theme has their own themes and these sub themes are mentioned according to their frequencies (n) and percentages (\%). As a result of the content analysis most comments were found on the theme "food", whereas the least comments were found on "price". The theme that got most positive comments was "food" whereas the theme that got most negative comments was "price" (See. Table 2).

Table 2. Customer Reviews on Gaziantep Restaurants Registered to TripAdvisor

\begin{tabular}{|l|c|c|c|c|c|}
\hline \multirow{2}{*}{ Category } & \multicolumn{2}{|c|}{ Positive } & \multicolumn{2}{c|}{ Negative } & \multirow{2}{*}{ Total* } \\
\cline { 2 - 5 } & $\begin{array}{c}\text { Number } \\
\text { (n) }\end{array}$ & $\begin{array}{c}\text { Percentage } \\
(\boldsymbol{\%})\end{array}$ & $\begin{array}{c}\text { Number } \\
(\mathbf{n})\end{array}$ & $\begin{array}{c}\text { Percentage } \\
(\mathbf{\%})\end{array}$ & \\
\hline Food & 1138 & 83 & 237 & 17 & 1375 \\
\hline Service & 440 & 71 & 177 & 29 & 617 \\
\hline Atmosphere & 235 & 56 & 182 & 44 & 417 \\
\hline Price & 164 & 46 & 193 & 54 & 357 \\
\hline
\end{tabular}


*The reason why the number of the reviews on food experience factors (2766) different from the number of total reviews investigated (1462) is each review usually involves more than one positive or negative comment.

\section{Results on Food Theme}

$80,3 \%$ of the comments on food theme were positive, whereas $19,7 \%$ of them were negative. Positive comments includes these themes; good flavor, very good flavor, local flavor, rich menu, satisfying, well presentation and a sub theme; qualified food. Negative comments include these themes; average flavor, small portion, fabrication, less local flavor, flavorless and a sub theme; disappointment. Positive and negative results about food theme are summarized in Table 3.

Table 3. Descriptive Statistics about Food Theme

\begin{tabular}{|l|c|c|l|c|c|}
\hline Positive & \multicolumn{2}{|c|}{$\% 80,3$} & Negative & \multicolumn{2}{c|}{$19,7 \%$} \\
\hline Sub Themes & $\mathbf{n}$ & $\mathbf{\%}$ & Sub Themes & $\mathbf{n}$ & $\%$ \\
\hline With Flavor & 244 & $36,9 \%$ & Average Flavor & 99 & $61,2 \%$ \\
\hline Very Flavor & 226 & $34,2 \%$ & Small Portion & 17 & $10,5 \%$ \\
\hline Local flavor & 59 & $8,9 \%$ & Fabrication & 12 & $7,5 \%$ \\
\hline Rich Menu & 43 & $6,5 \%$ & Less Local Flavor & 12 & $7,4 \%$ \\
\hline Satisfying & 36 & $5,5 \%$ & Flavorless & 11 & $6,7 \%$ \\
\hline Well Presented & 33 & $4,9 \%$ & Disappointment & 11 & $6,7 \%$ \\
\hline Qualified Food & 20 & $3,1 \%$ & \multirow{2}{*}{ Total } & \multirow{2}{*}{162} & $100 \%$ \\
\hline Total & 661 & $100 \%$ & & & \\
\cline { 1 - 2 }
\end{tabular}

Mostly used positive sub themes are having flavor (successful, really good...) and having rich flavor (diet enemy, flavor feast, splendid). These sub themes contain large part of the positive reviews. Local flavor is one of the important sub themes. One example of the comments for sub flavor themes is given below.

...I have never taste such flavors before. Appetizers are wonderful I feel like crazy which ever I taste .... (User 297)

One example of the comments for sub local flavor theme is given below.

... a place which presents traditional flavors rather than newly discovered flavors successfully... (User 593)

Mostly used negative sub theme is average flavor (ordinary, lame, below the standards, not remembered) and contains more than half of the negative sub themes. Examples of user comments for average flavor sub theme are given below.

...you can eat this qualified or more qualified food in anywhere... (User 857)

...flavors are good but not make you say wow... (User 365)

Other important sub themes are fabrication and less local food sub themes. Examples of user comments for these themes are given below. 
...This place where Gaziantep Cuisine must be seen serves Russian Salad and Paçanga pastry as appetizers which has nothing to do with Gaziantep Cuisine... (User 380)

\section{Results on Service Theme}

$73,8 \%$ of the sub themes for service theme were found positive whereas $26,2 \%$ of them were found negative. Positive reviews include these sub themes; fast service, tidy personnel, concerned personnel, cheerful personnel, good service, plenty of treats and hospitable. Negative reviews include these sub themes: bad service, careless personnel, slow service, dirty personnel and less treats. Results for service theme are summarized in Table 4.

Table 4. Descriptive Statistics for Service Theme

\begin{tabular}{|c|c|c|c|c|c|}
\hline Positive & \multicolumn{2}{|c|}{$73,8 \%$} & Negative & \multicolumn{2}{|c|}{$26,2 \%$} \\
\hline Sub Themes & $\mathbf{n}$ & $\%$ & Sub Themes & $\mathbf{n}$ & $\%$ \\
\hline Fast Service & 101 & $29,9 \%$ & Bad Service & 38 & $\begin{array}{c}31,7 \\
\%\end{array}$ \\
\hline Tidy Personnel & 61 & $17,9 \%$ & Careless Personnel & 38 & $\begin{array}{c}31,7 \\
\%\end{array}$ \\
\hline $\begin{array}{l}\text { Concerned } \\
\text { Personnel }\end{array}$ & 53 & $15,8 \%$ & Slow Service & 18 & $15 \%$ \\
\hline Cheerful Personnel & 37 & $10,9 \%$ & Dirty Personnel & 16 & $\begin{array}{c}13,3 \\
\%\end{array}$ \\
\hline Good Service & 33 & $9,7 \%$ & Less Treats & 10 & $8,3 \%$ \\
\hline Plenty of Treats & 27 & $7,9 \%$ & & & \\
\hline Hospitable & 27 & $7,9 \%$ & Total & 120 & $100 \%$ \\
\hline Total & 339 & $100 \%$ & & & \\
\hline
\end{tabular}

Mostly used positive sub themes are fast service, tidy personnel and caring personnel. Positive sub themes on service theme are mostly about personnel. Examples of comments on personnel sub theme are given below.

...Personnel lead you well and make you try each flavor... (User 85)

...A restaurant whose personnel make you feel special with their behaviors, efforts and hustle... (User 116)

...I have never seen personnel that much sincere and helpful before. They were here to help even how to drink ayran to how to eat baklava and made it without disturbing our eating pleasure... (User 674)

Mostly used negative themes are bad service and careless personnel. Some examples of comments for negative sub themes are given below.

...Yuvalama soup is good but with its terrible service, place and personnel flavor fall behind... (User 89) 
... Even though food and appetizer quality is really good, service is bad... (User 171)

... Personnel is always running, I do not know if number of personnel is less, however orders are not listened, if you can catch a waiter of course... (User 488)

...Waiters did everything for us to leave as quickly as possible... (User 846)

\section{Results on Atmosphere Theme}

$\% 51 \%$ of the mostly used sub themes for atmosphere theme was found positive whereas $49 \%$ were negative. Positive reviews include authentic, peaceful, beautiful, luxurious, different and natural sub themes. Negative reviews include crowded (very), noisy, hovel, disturbing, dirty, like a dining hall and average sub themes. Results on Atmosphere theme are summarized in Table 5.

Table 5. Descriptive Statistics about Atmosphere Theme

\begin{tabular}{|l|c|c|l|c|c|}
\hline Positive & \multicolumn{2}{|c|}{$51 \%$} & Negative & \multicolumn{2}{c|}{$49 \%$} \\
\hline Sub Themes & n & $\%$ & Sub Themes & n & $\%$ \\
\hline Authentic & 59 & $30,1 \%$ & Crowded (very) & 91 & $48,4 \%$ \\
\hline Clean & 58 & $29,5 \%$ & Noisy & 27 & $14,4 \%$ \\
\hline Peaceful & 32 & $16,3 \%$ & Hovel & 27 & $14,4 \%$ \\
\hline Beautiful & 25 & $12,7 \%$ & Disturbing & 17 & $9,0 \%$ \\
\hline Luxurious & 10 & $5,3 \%$ & Dirty & 17 & $9,0 \%$ \\
\hline Different & 8 & $4,0 \%$ & Dining Hall Like & 7 & $3,7 \%$ \\
\hline Natural & 4 & $2,0 \%$ & Average & 2 & $1,1 \%$ \\
\hline Total & 196 & $100 \%$ & Total & 188 & $100 \%$ \\
\hline
\end{tabular}

Mostly used positive themes are authentic and clean sub themes. Examples of user comments for positive sub themes are given below.

...It was very crowded, we had to wait a lot however it was worth it... (User 26)

... Later we drank ayran from local copper cups it was really authentic... (User 746)

...Place was really beautiful. Even though you do not drink or eat something place might have an effect on you... (User 164)

...However does it worth waiting and that noise? Yes!... (User 839)

Mostly used negative themes are crowded and noisy sub themes. Examples of user comments for negative sub themes are given below.

...First of all it was really crowded and noisy. It is impossible of eat tastefully at a place like this... (User 501)

...The only problem was the crowd. Crowd and fork, knife noises can be disturbing sometimes... (User 703) 


\section{Results on Price Theme}

$40,7 \%$ of the mostly used sub themes related to price theme were found positive whereas 59, $3 \%$ of them were found negative .Positive reviews consist of appropriate and average sub themes. Negative reviews consist of high, little bit expensive and high for Gaziantep sub themes. Results on price theme are summarized on Table 6.

Table 6. Descriptive Statistics for Price Theme

\begin{tabular}{|l|c|c|l|c|c|}
\hline Positive & \multicolumn{2}{|c|}{$40,7 \%$} & Negative & \multicolumn{2}{c|}{$59,3 \%$} \\
\hline Sub Themes & $\mathbf{n}$ & $\%$ & Sub Themes & n & $\%$ \\
\hline Appropriate & 83 & $76,8 \%$ & High & 128 & $81,5 \%$ \\
\hline Average & 25 & $23,2 \%$ & A little bit Expensive & 19 & $12,1 \%$ \\
\hline \multirow{2}{*}{ Total } & \multirow{2}{*}{108} & \multirow{2}{*}{$100 \%$} & High for Gaziantep & 10 & $6,3 \%$ \\
\cline { 4 - 6 } & & & Total & 157 & $100 \%$ \\
\hline
\end{tabular}

Mostly used positive sub theme was appropriate whereas mostly used negative sub theme was high. Related to this, some users stated the prices are high for Gaziantep. Even though Users generally commented that prices were high, they though it was worth to the service and food. Examples of positive and negative comments for price theme are given below.

...Eat more qualified food with fewer prices... (User 8)

... You can find cheaper and more flavored kinds of the food that you eat here within cities, in

average local managements... (User 167)

...Prices seem high but it is worth it... (User 12)

\section{RESULTS AND EVALUATION}

As it is seen, under the scope of tourism eating - drinking behavior means both an attraction element and presenting the local cultures especially for the managements which give that service. So, reviews of the visitors who had eating-drinking experience within these managements, on social media might be a key presentation or information base for other people. From this point of view, top 7 local food-beverage managements in Gaziantep that got highest number of comments on TripAdvisor web site were investigated and 1462 Turkish comments were analyzed. Results, findings through literature and applicators can be summarized as follows. 


\section{Theoretical Implications}

As a result of the descriptive analysis, most of the comments are related to 'food 'theme whereas least of the comments are related to 'price' theme. What is more 'food and service' got the highest number of positive comments whereas 'atmosphere and price' got the highest number of negative comments. These findings show similarity with the findings of $\mathrm{Su}$ and Bowen's (2000) study which stated that the commonly faced problems for customers within a la carte restourants are 'being not worth to the price' with the findings of Liu and Jang (2009) which stated that one of the factors that needs to be developed within Chineese restourants is 'hygiene', of Kitapç1 (2008) which stated that the factor $57,4 \%$ of the customers complaint about is 'not being hygienic', of Albayrak's (2013) study which stated that 'personal hygiene of the personnel' is complained by customers mostly, of Şahin, Çakıcı and Güler's (2014) research which stated that one of the basic factors for a la carte restourants to get customer complaints is 'atmosphere of the restourant', of Dalgıç, Güler and Birdir's (2016) study, which revealed that one of the mostly complained factor by customers id 'unfair prices', of Arsezen Otamış's (2015) study which stated that factors that are found mostly positive are 'service and food quality' whereas mostly negative are 'price and atmosphere' , of Lei ve Law's (2015) study in which it is mentioned that price is the most negatively perceived factor in restourants by customers, of Zorlu, Çeken and Kara's (2013) study on thermal managements which stated that top one complaining reason for restourant services by customers is 'problems related with atmosphere', of Özaslan and Uygur's (2014) study where most commonly faced problems by customers are listed as 'unfair prcies', 'dirty sinks and bathrooms' and 'dirty environment' within literature. Basic difference with the studies mentioned before and present study is that dissatisfaction about service quality and food quality through local restourants are not as high as former studies. Even though dissatisfaction from service quality is higher than food quality, total negative reviews on these two factors nearly equal to the dissatisfaction from service atmosphere and lower than the dissatisfaction from prices.

\section{Practical Implications}

Present study which evaluates positive and negative local flavor experiences of consumers includes lots of results and suggestions that local restaurants primarily the ones in Gaziantep and in other cities and also ethnical restaurant managements can benefit from. According to this when customers' comment on food concept investigated carefully, delicious $(36,9 \%)$ or very delicious $(34,2 \%)$ perspectives are the leadings one within positive comments. However, related to this theme leading negative comments include that $61.2 \%$ of the customers thought flavor of the dishes were ordinary. Even though it is a small ratio $10.5 \%$ of the customers stated that they found portions small. On this point, managements need to be more careful about food that they claim local, use original ingredients, be careful about quality and originality of the 
ingredients and need to have bigger portions in order to make their customers satisfied and leave positive comments about themselves, which in turn they can benefit from.

When customers' comments about service theme are evaluated, $73.8 \%$ of the reviews are found positive whereas $26,2 \%$ of them are found negative. At this point while it can be said that customers are generally satisfied by the services done by local food and beverage managements in Gaziantep, it is really remarkable that hospitality is the least used word for positive comments $(7.9 \%)$. Quality of the service communication between personnel and customer is an important hint for service quality perception by customers (Groth and Grandey, 2012). Generally, basic evaluation, done by customers for a management is a result of evaluation done within the time period that is spend in management and to all its elements (Shamdasani and Balakrishnan, 2000). Because of that reason, it is important for managements to have an effective service relation with the customers (del Rio-Lanza, Casielles and Diaz-Martin, 2009). Local restaurants in Gaziantep are suggested to make customers' perception on hospitality stronger in order to have positive behavioral tendencies for future.

When atmosphere theme which is another theme customers' comments are classified under, factors related to this theme are found to get $51 \%$ of positive comments whereas $49 \%$ of negative comments. The word authentic was mostly used within positive point of views $(30.1 \%)$ whereas the word crowded (much) was mostly used for negative reviews with $48,4 \%$ ratio. In relation to these it can be thought customers found places authentic in accordance with the local cuisine whereas the definition crowded for these places is seem as an important problem. At that point it is suggested that restaurants need to take necessary action for lowering the crowd perception.

Expensiveness perceptions on local flavors by customers become prominent as the last but not the least factor. 59, $3 \%$ of the customers left negative comments about price policies of the managements, within $81,5 \%$ of these comments high prices were mentioned. At this point it must be mentioned that price is highly manipulative (contradictive) and subjective criteria for evaluating eating experience. However, managements need to provide qualified service which makes customer to think the perceived service performance was worth to monetary and non-monetary expenses and the thing they get was fair.

\section{LIMITATIONS AND SUGGESTION FOR FURTHER STUDIES}

Similar to all other studies, present study was done with some limitations. First limitation is having customer comments only related to Gaziantep, second one is having customer comments only on restaurants that serve local food, third one is having these comments only from TripAdvisor website, forth one is having only Turkish comments and the last one is limiting the comments to the themes which were mentioned within the method section of the study, and not including comments on other themes. These limitations might create lots of new study topics for the researchers who want to study on similar topics. Considering the importance and originality for literature a research 
design which (a) compares positive and negative comments of customers and managements on service, (b) compares positive and negative customer comments on services for different restaurant types, (c) compares customer reviews on service quality of restaurant managements in cities which have similar gastronomic features, (d) compares local and foreigner customer reviews on restaurant quality evaluations, (e) evaluates customer comments for Turkey's cuisine culture and service quality on foreigner customer commenting portals and gastronomy forums for management reviews, (f) evaluates themes like customer complaint types, future behavioral tendencies, positive and negative reactions rather than mostly used service, food, atmosphere and price themes and ( $\mathrm{g}$ ) evaluates relations between variables by using qualitative analysis programs might be beneficial.

\section{REFERENCES}

1. Albayrak, A. (2013). Restoran işletmelerinde müşteri şikâyetleri ve şikâyete ilişkin davranışlar. Paradoks Ekonomi, Sosyoloji ve Politika Dergisi, Cilt 9, Sayı 2: 27-51.

2. Arsezen Otamış, P. (2015). Fethiye'de TripAdvisor'a kayıtlı yiyecek içecek işletmeleri için kritik başarı faktörleri ve sosyal ă̆ analizi ile performans değerlendirmesi. Journal of Gastronomy and Tourism Studies, 3 (2): 31-39.

3. Aslan, Z., Güneren, E., \& Çoban, G. (2014). Destinasyon markalaşma sürecinde yöresel mutfağın rolü: Nevşehir örneği. Journal of Tourism and Gastronomy Studies, 2(4), 3-13.

4. Baker, D. A., \& Crompton, J. L. (2000). Quality, satisfaction and behavioral intentions. Annals of tourism research, 27(3), 785-804.

5. Battallar, Z. ve Cömert, M. (2015). Tüketicilerin Tercihlerinde Sosyal Medyadaki Reklamların Etkisi. Turizm Akademik Dergisi, 2(1), 39-48.

6. Bessière, J. (1998). Local development and heritage: traditional food and cuisine as tourist attractions in rural areas. Sociologia ruralis, 38(1), 21-34.

7. Cömert, M. ve Özata, E. (2016). Tüketicilerin Yöresel Restoranları Tercih Etme Nedenleri Ve Karadeniz Mutfağı Örneği. Uluslararası Sosyal Araştırmalar Dergisi, 9(42), 1963-1973.

8. Dalgıç, A., Güler, O. ve Birdir, K. (2016). Tripadvisor.com'da Yer Alan Restoran Şikâyetlerinin Analizi: Mersin ve Hatay'da Yöresel Yiyecek Sunan Restoranlara Yönelik Bir Araştırma (Analysing Restaurant Complaints Available at Tripadvisor.com: A Study on Local Food Restaurants Located in Mersin and Hatay/Extended Abstract). Journal of Tourism and Gastronomy Studies (JOTAGS), Vol.4 (1), 153-173.

9. del Río-Lanza, A. B., Vázquez-Casielles, R., \& Díaz-Martín, A. M. (2009). Satisfaction with service recovery: Perceived justice and emotional responses. Journal of Business Research, 62(8), 775-781.

10. Elder, J., Sallis, F. J., Zive, M. M., Hoy, P., Mckenzie, L. T., Nader, R. P. ve Berry, C. C. (1999). Factors affecting selection of restaurants by Anglo and 
Mexican-American families. Journal of the American Dietetic Association, 99 (7): 856-858.

11. Ekici, M. (2008). Geleneksel Kültürü Güncellemek Üzerine Bir Değerlendirme. Millî Folklor 80, 33-38.

12. Eraslan Uludağ, R. (2013). Sosyal Medya Her An ve Her Yerde Görünür Olmak. The Turkish Online Journal of Design, Art and Communication - TOJDAC, 3(4), 29-37.

13. Erkol, G. ve Zengin, B. (2015). Şanlıurfa'da Bulunan Yöresel Yiyecek-İçecek İşletmelerinin Pazarlama Stratejilerinin Şehrin Turizm Açısından Pazarlanabilirliğine Etkileri. Akademik Sosyal Araştırmalar Dergisi, 3(9), 599614.

14. Ertaş, Y. ve Gezmen-Karadağ, M. (2013). Sağlıklı Beslenmede Türk Mutfak Kültürünün Yeri. Gümüşhane Üniversitesi Sağlık Bilimleri Dergisi, 2(1), 117-136.

15. Eryılmaz, B. ve Şengül, S. (2016). Sosyal Medyada Paylaşılan Yöresel Yemek Fotoğraflarının Turistlerin Seyahat Tercihleri Üzerindeki Etkisi. Uluslararası Türk Dünyası Turizm Araştırmaları Dergisi, 1(1), 32-42.

16. Gaziantep Gastronomy, http://www.gastroantep.com.tr/ [accessed 29 March 2016].

17. Gaziantep Cuisine,

(2016). http://www.gaziantepmutfagi.org/Tourism,gaziantepen,106.html [accessed 29 March 2016]

18. Groth, M., \& Grandey, A. (2012). From bad to worse: Negative exchange spirals in employee-customer service interactions. Organizational Psychology Review, 126.

19. Heung, V. ve Gu, T. (2012). Influence of restaurant atmospherics on patron satisfaction and behavioral intentions. International Journal of Hospitality Management, 31(4), 1167-1177.

20. Kesici, M. (2012). Kursal turizme olan talepte yöresel yiyecek ve içecek kültürünün rolü. Karamanoğlu Mehmetbey Üniversitesi Sosyal ve Ekonomik Araştırmalar Dergisi, 2012(2), 33-37.

21. Kızılırmak, İ., Albayrak, A. ve Küçükali, S. Yöresel Mutfağın Kırsal Turizm İşletmelerinde Uygulanması: Uzungöl Örneği. Uluslararası Sosyal ve Ekonomik Bilimler Dergisi, 4 (1), 75-83.

22. Kim, H. J., Park, J., Kim, M. J., \& Ryu, K. (2013). Does perceived restaurant food healthiness matter? Its influence on value, satisfaction and revisit intentions in restaurant operations in South Korea. International Journal of Hospitality Management, 33, 397-405.

23. Kitapçı, O. (2008). Restoran Hizmetlerinde Müşteri Şikayet Davranışları: Sivas İlinde Bir Uygulama, Erciyes Üniversitesi, İktisadi ve İdari Bilimler Fakültesi Dergisi, Say1 31:111-120.

24. Kodaş, D. ve Dikici, E. (2012). Ahlat, Kursal Bölgesinde Gastronomi Turizminin Muhtemel Toplumsal Etkileri Üzerine Nitel Bir Çalışma. Aksaray Üniversitesi İktisadi ve İdari Bilimler Fakültesi Dergisi, 4(2), 51-68. 
25. Korkmaz, S. (2005). Fast food (hızlı yemek) pazarında rekabetçi stratejilerin etkinliği: Üniversite gençliğinin tercihlerinin analizi. Ticaret ve Turizm Eğitim Fakültesi Dergisi, 2, 22-39.

26. Kolodinsky, J. (1992). A system for estimating complaints, complaint resolution and subsequent purchases of professional and personal services. Journal of Consumer Satisfaction, Dissatisfaction and Complaining Behavior, 5, 36-44.

27. Law, R., To, T. ve Goh, C. (2008). How do Mainland Chinese travelers choose restaurants in Hong Kong?: An exploratory study of individual visit scheme travelers and packaged travelers. International Journal of Hospitality Management, 27(3), 346-354.

28. Lee, L. E., Niode, O., Simonne, A. H. ve Bruhn, C. M. (2012). Consumer perceptions on food safety in Asian and Mexican restaurants. Food Control, 26(2), 531-538.

29. Lei, S. ve Law, R. (2015). Content Analysis of Tripadvisor Reviews on Restaurants: A Case Study of Macau, Journal of Tourism 16 (1),17-28.

30. Ma, G. (2015). Food, eating behavior, and culture in Chinese society. Journal of Ethnic Foods, 2(4), 195-199.

31. Namkung, Y. ve Jang, S.S. (2007). Does food quality really matter in restaurants? Its impact on customer satisfaction and behavioral intentions. Journal of Hospitality \& Tourism Research, 31(3), 387-409.

32. Oliver, R. L. (1980). A cognitive model of the antecedents and consequences of satisfaction decisions. Journal of marketing research, 460-469.

33. Özaslan, Y. ve Uygur, S. M. (2014). Negatif Ağızdan Ağıza İletişim (Wom) ve Elektronik Ağızdan Ağıza İletişim (E-Wom): Yiyecek-İçecek İşletmelerine Yönelik Bir Araştırma. Ataturk University Journal Of Economics \& Administrative Sciences, 28(3), 69-88.

34. Özlü, Z. (2006). XVIII. Yüzyılın İkinci Yarısında Gaziantep Mutfağı. Millî Folklor, 18(72), 118-128.

35. Sabbağ, Ç. (2015). Gaziantep Yeme İçme Kültürü. Fırat'tan Volga'ya Medeniyetler Köprüsü (Ed. R. Yarullina Yıldırım). Adıyaman Üniversitesi Yayınlar1, sy.289-303.

36. Serçeoğlu, N., Boztoprak, F. ve Tirak, L. (2016). Gastronomi Turizmi İle Şehir Markalaşması İlişkisi: Atatürk Üniversitesi Öğrencileri. Journal of Tourism and Gastronomy Studies, 4(2), 94-114.

37. Shamdasani, P. N., \& Balakrishnan, A. A. (2000). Determinants of relationship quality and loyalty in personalized services. Asia Pacific Journal of Management, 17(3), 399-422.

38. Silsüpür, Ö. G. Ö. (2016). Popüler ve Tüketim Kültürü Bağlamında Gazetelerin Haftasonu Eklerinde Sundukları Yaşam Tarzları. İnönü Üniversitesi İletişim Fakültesi Elektronik Dergisi (INIIF E-Dergi), 1(1), 122-138.

39. Su, W. Y. ve Bowen, J. T. (2000). Restaurant customer complaint behavior. Journal of Restaurant \& Foodservice Marketing, 4(2), 35-65. 
40. Sulek, J. M., \& Hensley, R. L. (2004). The relative importance of food, atmosphere, and fairness of wait the case of a full-service restaurant. Cornell Hotel and Restaurant Administration Quarterly, 45(3), 235-247.

41. Sü Eröz, S. ve Doğdubay, M. (2012). Turistik Ürün Tercihinde Sosyal Medyanın Rolü ve Etik İlişkisi. Dokuz Eylül Üniversitesi İktisadi ve İdari Bilimler Fakültesi Dergisi, 27(1), 133-157.

42. Şahin, A., Çakıcı, C. ve Güler, O. (2014). Tüketicilerin Masa Servisi Yapan Restoranlarda Önem Verdiği Hususların Şikâyet Davranışı Eğilimlerine Etkisi, 15. Ulusal Turizm Kongresi, Ankara, ss:683-700.

43. Şengül, S. ve Türkay, O. (2015). Bölge Restoran Mönülerinin Belirlenmesinde "Yöresel Mutfaklar" Eğitiminin Kullanılması: Mudurnu Örneği. Electronic Journal of Vocational Colleges, Uluslararası Meslek Yüksekokulları Sempozyumu (UMYOS) Özel Sayısı.

44. Tayfun, A. ve Tokmak, C. (2007). Tüketicilerin Türk usulü fast food işletmelerini tercih etme sebepleri üzerine bir araştırma. Elektronik Sosyal Bilimler Dergisi, 6(22), 169-183.

45. Taylan, H.H. ve Arklan, Ü. (2008). Medya ve Kültür: Kültürün Medya Aracılığıyla Küreselleşmesi. Sosyal Bilimler Dergisi, 10(1), 86.

46. Tellström, R., Gustafsson, I. B. ve Mossberg, L. (2006). Consuming heritage: The use of local food culture in branding. Place Branding and Public Diplomacy,2(2), $130-143$.

47. UNESCO (2015). "Gaziantep Unesco Yaratıc1 Şehirler Ağında" http://unesco.org.tr/dokumanlar/duyurular/gaziantepuys.pdf (Erişim: 26.06.2016)

48. Vural Akıncı, Z.B. ve Bat, M. (2010). Yeni Bir İletişim Ortamı Olarak Sosyal Medya: Ege Üniversitesi İletişim Fakültesine Yönelik Bir Araştırma. Journal of Yaşar University, 20(5), 3348-3382.

49. Wahlqvist, M. L. ve Lee, M. S. (2007). Regional food culture and development. Asia Pacific journal of clinical nutrition, 16(S1), 2-7.

50. Yıldırım, A. ve Şimşek, H. (2011). Sosyal Bilimlerde Araştırma Yöntemleri: Seçkin Yayıncılık.

51. Yazıcıŏ̆lu, İ., Işın, A. ve Koç, B. (2013). Üniversite Öğrencilerinin Fast Food Ürünleri Tercih Etme Nedenleri. Journal of Tourism and Gastronomy Studies, Cilt 1, Say1 1, 36-41.

52. Zağralı, E. ve Akbaba, A. (2015). Turistlerin Destinasyon Seçiminde Yöresel Yemeklerin Rolü: İzmir Yarımadası'nı Ziyaret Eden Turistlerin Görüşleri Üzerine Bir Araştırma. Journal of Yaşar University, 10(40), 6633-6644.

53. Zengin, B., Uyar, H. ve Erkol, G. (2014). Gastronomi Turizmi Üzerine Kavramsal Bir Inceleme. 15. Ulusal Turizm Kongresi, 13-16 Kasim 2014, Gazi Üniversitesi, Ankara.

54. Zhang,Z., Ye, Q., Law,R., Li, Y. (2010). The impact of e-word-of-mouth on the online popularity of restaurants: Acomparison of consumer reviews and editor reviews. International Journal of Hospitality Management, Vol. 29, 694-700. 
55. Zorlu, Ö., Çeken, H. ve Kara, A. M. (2013). Otel işletmelerinde restoran şikâyetlerinin şikâyet davranışlarına etkisi: Afyonkarahisar ili örneği. Dokuz Eylül Üniversitesi Sosyal Bilimler Enstitüsü Dergisi, 15(3), 529-554. 